\title{
Management of engineering knowledge in information-educational environment of transport enterprises
}

\author{
JEL: 018 DOI: 10.24136/atest.2018.549 \\ Data zgłoszenia: 19.11.2018 Data akceptacji: 15.12.2018
}

The article deals with the issues of engineering knowledge management for the formation of information and educational environment of the transport enterprise. The possibilities of transformation of information, experience and competence of engineering personnel into knowledge used for its group and individual training based on adaptive training system are analyzed.

Keywords: management, learning organization, knowledge monitoring, adaptive learning, transport.

\section{Introduction}

The transport enterprise is a separate legal and economic unit, the activity of which is the provision of transport services [12]. Regardless of the mode of transport, we will highlight the main functions of the transport enterprise engineer:

- development of sound recommendations on logistics and supply chain management;

- development of optimal route deliveries in the specified time frame;

- organization of work on the safety of goods and just in time delivery to their recipients;

- preparation of instructions for the maintenance of goods and transport documents;

- technical diagnostics, repair and maintenance of vehicles and equipment;

- planning and provision of measures for the safety of transport and loading and unloading operations, labor protection, fire safety, etc.

This is not a complete list of the engineer functions taken from the latest job advertisements for vacant engineering positions of transport enterprises. The list of functions will increase significantly if we consider the different modes of transport (for example, air, rail, road, water, pipeline and cable transport), its purpose and infrastructure. Studying the needs of different modes of transport, it turns out that transport enterprises need specialists from many branches of engineering. For example, such branches of engineering as civil engineering, computer engineering, electrical engineering, industrial engineering, mechanical engineering, software engineering etc. To perform its functions, an engineer should have a deep knowledge of a specialty, as well as general engineering knowledge in related fields. Initially, the engineer receives such knowledge during training in profile higher school. In the process of working in the transport enterprise the engineer improves his knowledge considering the specifics of functions, changing conditions of labor, the emergence of new technical products and tools, information technology and support systems etc. The need to improve the skills of engineering personnel of the transport enterprise is associated with the development of information and transport technologies that determine the conditions for rapid changes in the external environment. Therefore, it is important for the development of the enterprise and its engineering staff to create of organizational training, which is aimed at improving its competitiveness in the market of transport services, allows to implement new methods, tools and technologies in its activities [14]. It is obvious that the future will be successful for those transport companies that in their management concept will learn to use the principles of the learning organization [13,14].

The peculiarity of the learning organizations is not only continuously self-learning staff. This is, above all, a culture of organizational learning and development, in which engineering staff is open to continuous collective improvement. It is continuous training in a group of like-minded people that contributes to the synergetic effect of knowledge generation, the development of individual abilities of engineering personnel. There are a lot of definitions of the learning organization. For Example, D. A. Garvin proposed the most comprehensive definition of a learning organization, according to which the essence of such an organization is the fluency in the tasks of creating, acquiring and transferring knowledge, as well as changing their behavior in response to new knowledge and experience [4]. It is also possible to define a learning organization as a knowledge management organization to acquire new competitive knowledge.

According to Peter M. Senge, the learning organization's functioning style is based on five disciplines:

1) the discipline of mental models' management;

2) the discipline of vision building;

3) the discipline of a group learning;

4) the discipline of personal growth and learning;

5) the discipline of system thinking [14]

The fifth discipline is fundamental for the learning organization. This is a representation of the organization as a system of knowledge, the ability of a holistic view of the processes and phenomena occurring in time and the ability to predict the prospects of the future.

Highlighting the fifth discipline as fundamental, the role and importance of the other four disciplines in shaping the future competitive advantage of the organization should not be underestimated. In my opinion, group learning is important when the interaction of team members on the learning process creates a new perception of the problems and models of their most effective solutions. The group learning is mutually beneficial for all team members regardless of their intellectual level, knowledge and experience. Only group learning can quickly develop the engineering staff of the enterprise.

Without challenging the role and importance of group learning, it is also necessary to emphasize the desire of each member of the group for individual growth and self-learning as a condition for the perception of group information and knowledge. Self-learning is directed for the implementation of operational and tactical goals of the group and the enterprise. Each self-learning is associated with the study of previous experience and knowledge, problem questions and their answers, modeling different situations and finding rational ways of their engineering solutions. In self-learning, it is important not only to study external sources of information (books, articles, patents, internships, obtaining a second engineering education in higher education, refresher courses, trainings, conferences and seminars, individual communication with colleagues of other organi- 
zations, etc.), but also sources of information within the enterprise and the group.

The creation of the information-educational environment for the group and individual learning of the engineering personnel of the transport enterprise is an important task of its competitive development. The engineering knowledge and experience of the personnel saved up by the enterprise are a source of functioning and development of the information-educational environment as a basic resource of the learning organization. It is this environment that gives a comprehensive idea of the current state of the enterprise, the prospects and directions of its development, the creative potential of engineering personnel, the possibilities of innovative engineering solutions.

Engineering knowledge management is a systematic process of transformation of information, experience and competence of engineering personnel into knowledge necessary to create competitive advantages of the enterprise and its successful functioning. There are different models for transforming information, experience and competencies into knowledge. From the known models the resource model is allocated, which is based on the concept of key competencies, skills of staff and is based on effective interaction between the five elements [10, 14]:

- key skills covering the knowledge and skills of personnel, technical systems, management systems, organizational standards and values;

- import knowledge from the environment;

- implementation and integration of new tools and technologies;

- experimentation;

- joint problem solving and knowledge sharing.

The analysis of these five elements of effective knowledge management shows that one of the ways to implement them is to create an information-educational environment in the enterprise, aimed at the transformation of information, experience and competence in the knowledge of engineering personnel. The perspective direction of development of the learning organizations is a knowledge management for the formation of the informationeducational environment at the enterprise for the group and individual learning of its engineering personnel.

\section{The engineering knowledge management system}

for formation of information-educational environment

at the transport enterprise

The engineering knowledge management system of the enterprise for the formation of the information-educational environment of the transport enterprise provides information support, transformation of information, competencies and experience of the engineering personnel into knowledge, the group and individual learning of specialists, the formation of new knowledge, competencies to create a competitive advantage.

Information support of the enterprise allows to collect, search for information from the database of the enterprise, as well as from external sources, access to information from the database of the enterprise, its exchange, transfer, storage and use.

The transformation of information, competences and experience of engineering personnel into knowledge includes monitoring, classification and systematization of information; its assessment from the point of view of importance for the enterprise; synthesis of information into knowledge; presentation of the acquired knowledge mainly in electronic form suitable for storage and subsequent use; individual, group and corporate evaluation of the results; formation of knowledge units in a public form for use in information resources of the enterprise. The knowledge, which is presented in the information resources of the enterprise, is its intellectual capital, which is subject to accounting, monitoring, storage, accumulation and periodic updating.

The group learning of the engineering personnel implies common goals, common vision, personal motivation and continuous self-learning to achieve the goals of the group, the emergence of new knowledge, ideas, innovative solutions because of joint training, discussion, and dialogue. The result of group learning can be a new vision of situations, problems and ways to solve them, the improvement of previously obtained technical and logistics solutions, the creation of innovative proposals etc. Along with the group learning, self-training of the engineering personnel plays an important role, which makes it possible to integrate individual knowledge at a higher level and contributes to the manifestation of synergetic effects.

The formation of new knowledge, competencies to create a competitive advantage of the enterprise is only because of the group learning. New knowledge is formed if it is presented in a public form for use in information resources of the enterprise.

The analysis of the engineering knowledge management system of the information-educational environment of the enterprise shows that the creation of new competitive knowledge and intellectual potential is associated with the organization of group learning of engineering personnel. Thus, the group learning of personnel at the enterprise is a full-fledged strategic activity for professional training of the engineering personnel.

\section{Adaptive learning systems for the group}

and individual training of engineering personnel

In the learning organizations can be identified several methods that are in one form or another used for the group and individual learning and development of engineering personnel. For example, mentoring, coaching, "training areas", stakeholder institution, peer reviews and a 360-degree feedback. The role and importance of these methods in the learning and development of personnel is different and does not always contribute to obtaining complete and comprehensive information about the effect of training, initiating the transfer of necessary knowledge and experience. The need to develop a system of continuous group and individual learning in an environment of equal partnership is obvious.

Modern e-technologies contribute to the creation of informationeducational environment in the enterprise using automated adaptive learning system (ALS) [1, 3 and 15]. The ALS provides training material that has been implemented because of individual or collective engineering solutions in the enterprise. The learning material can be presented in a convenient form for perception, for example, in a multimedia form [7]. In the ALS is used teaching material, which was prepared by the direct executor of the engineering solution of the task. The learning material is presented by the ALS in the form of test items of three levels of complexity. The levels of complexity of the test items are set by a phased decomposition of the main test item, which represents the highest level of complexity and covers one of the main parts of the solution. The ALS contains reference solutions of the presented engineering problem, which were entered by the executor into its database. Reference solutions of the engineering problem are used for expert comparison. The prepared learning material can be presented in a public form for use in the information resources of the enterprise after its discussion in the group of specialists.

Initially, the members of the group, answering the test tasks, get acquainted with the essence of the question and try to find optimal solutions. If the solutions of the highest level of complexity do not coincide with the reference solution, they pass to the solution of the second and third levels of complexity. The next step is to familiarize 
the group members with the reference solutions at each level of complexity of the test items and personal assessment of each engineering solution. The overall comprehensive assessment of engineering solutions is calculated as the average rating of all members of the group who took a part in the testing [8]. The result of this work is the group acceptance of optimal reference solutions of the problem under consideration [9], which turn into unified solutions of such engineering problems.

The presented learning material after the adjustments made by members of the group can be tested by the engineering personnel of other groups of the transport enterprise. This approach to adaptive learning allows to involve engineers of different specialties in interactive training. In this mode, the ALS assess the knowledge level of engineers and candidates for vacancies. The ALS allows you to assess the risks associated with incorrect assessment of the level of knowledge that meets the requirements of the quality standard ISO 9000 [14]. Such learning materials can also be used in the training of students in high schools [2] and in distance learning using licensed software [6].

For the organization of the engineering personnel interactive training in the transport enterprise can be used for "training areas", seminars, internships, trainings. Such training within the organization helps to identify contradictions in the strategy, promotes of system thinking in an environment as close to real conditions. Candidates for vacancies, students of specialized higher schools may be invited to such events. It is possible to organize training center of the transport enterprise to improve the skills of engineering personnel of other organizations.

Implementation of the proposed adaptive learning of engineering personnel is possible with the help of universal software, for example, based on Teachbase (Corporate Education Platform) or LMS Moodle (Modular Object-Oriented Dynamic Learning Environment) [5].

\section{Conclusion}

The application of the proposed system of engineering knowledge management in the information-educational environment of the transport enterprise based on the use of adaptive learning systems will allow:

- to provide group and individual motivated learning of engineering personnel of the enterprise;

- to eliminate gaps in knowledge and experience;

- to align the level of competence and skills of engineering personnel;

- to realize the interchangeability of staff in solving repetitive tasks;

- to identify the needs for knowledge and competencies in the light of environmental changes,

- to conduct professional selection of candidates for employment;

- to facilitate the exchange of knowledge and the search for new information;

- to reuse of engineering solutions;

- to create conditions for self-realization of engineering personnel,

- to provide the possibility of distance learning.

The transformation of information, competence and experience of engineering personnel into knowledge accumulated and presented in the databases of the adaptive learning system contributes to their preservation in the form of knowledge capital of the transport enterprise. Decomposition analysis of already solved engineering problems allows to unify approaches to solving individual elements of new problems. Continuous replenishment of learning material for the adaptive learning system in the form of test items with decomposition contributes to the improvement of engineering decisions made through individual and group discussion. Optimization and unification of engineering solutions helps to reduce costs and timelines for accepting solitions, contributes to the development of strategic plans for the development of technical infrastructure and engineering potential of the enterprise.

\section{Bibliography:}

1. Brusilovsky, P., Christoph, P., Adaptive and Intelligent Webbased Educational Systems, International Journal of Artificial Intelligence in Education. (IJAIED), 2003, 13 (2-4), 159-172.

2. Dzhuguryan, L., Dzhuguryan, T., System kształcenia i monitoringu wiedzy w Polsce, Materials the 21st International Scientific and Methodological Conference „Education Quality Management of Specialists", Odessa State Academy of Civil Engineering and Architecture, (Ukraine), Part. 1, 2016, 5-6.

3. Dzhuguryan T.G., Tonkonogy V.M., Dzhuguryan L.A., Автоматизированная адаптивная система обучения и контроля знаний, High-technologies in the Mechanical Engineering, Scientific Proceedings of National Technical University of Kharkov Polytechnic Institute, (Ukraine), 1(12), 2006, 141150, (ros).

4. Garvin D.A., Building a Learning Organization, Harvard Business Review on Knowledge Management, Harvard Business School Press, Boston, MA, 1998.

5. Horvat, Ana; Dobrota, M.; Krsmanovic, M.; \& Cudanov, M., Student perception of Moodle learning management system: a satisfaction and significance analysis, Interactive Learning Environments. 23 (4), 2015: 515-527.

6. Jelonek D., Chluski A., Rola agentów programowych w nauczaniu na odległość (The role of software agents in distance education), "Business Informatics", 17(118), 2010, 89-92.

7. Klaučo R., Várkoly L., Multimedia and teaching efficiency. [w:] Kiełtyka L. (Ed.): IT Tools in Management and Education. Selected Problems, The Publishing Office of Czestochowa University of Technology, Częstochowa 2011, 125-131.

8. Kolomiec L.V., Dzhuguryan L.O., Комплексна модульна оцінка знань 3 використанням адаптивних навчальноконтролюючих систем, Bulletin of Engineering Academy of Ukraine, Issue 1, 2010, 72-76, (ukr).

9. Kolomiec L.V., Dzhuguryan L.O., Прийняття рішень при оцінці знань на основі даних комплексного контролю 3 використанням систем автоматизованого навчання, Bulletin of Engineering Academy of Ukraine, Issue 1, 2010, 72-76, (ukr).

10. Leonard-Barton D., Wellsprings of Knowledge. Building and Sustaining the Sources of Innovation, Harvard Business School, CRC Press, Boca Raton, 1995.

11. PN-EN ISO 9000:2015-10, Systemy zarzadzania jakościa Podstawy i terminologia, Polski Komitet Normalizacyjny, Warszawa 2015, s. 26; PN-EN ISO 9001:2015-10, Systemy zarzadzania jakościa - Wymagania, Polski Komitet Normalizacyjny, Warszawa 2015.

12. Przedsiębiorstwo. W: red. Bogdan Miedziński, Stefan Biczyński: Słownik ekonomiki i organizacji przedsiębiorstwa. Warszawa: Państwowe Wydawnictwo Ekonomiczne, 1991.

13. Trajer J., Paszek A., Iwan S., Zarządzanie wiedza, Polskie Wydawnictwo Ekonomiczne, Warszawa, 2012.

14. Senge P.M., Piąta dyscyplina. Teoria i praktyka organizacji uczacych się, Wolters Kluwer, Warszawa, 2012.

15. Tonkonogy V.M., Dzhuguryan L.O., Kolesnikova K.V., Автоматизированная интеллектуальная система обучения и контроля знаний практического материала графических дисциплин, High-technologies in the Mechanical Engineering, Scientific Proceedings of National Technical University of Khar- 
kov Polytechnic Institute, (Kharkov, Ukraine), 1(13), 2007, 114123 , (ros)

\section{Zarządzanie wiedzą inżynierską w środowisku informacyjno- edukacyjnym przedsiębiorstw transportowych}

W artykule omówiono problematykę zarządzania wiedzą inżynierska dla tworzenia środowiska informacyjno-edukacyjnego przedsiębiorstwa transportowego. Przeanalizowano możliwości transformacji informacji, doświadczenia i kompetencji kadry inżynierskiej w wiedzę wykorzystywana do szkolenia grupowego i indywidualnego w oparciu 0 adaptacyjny system szkoleniowy.

Słowa kluczowe: zarządzanie, organizacja ucząca się, monitoring wiedzy, nauczanie adaptacyjne, transport.

Autorka:

mgr inż. Lyudmyla Dzhuguryan - Szczecin, e-mail: I.dzhuguryan@gmail.com 